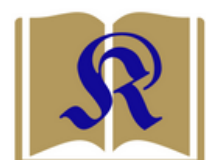

KURIOS

\title{
Pelayanan Bersama Komunitas Sebagai Model Pelayanan Pastoral Berbasis Paradigma Komunal-Kontekstual dalam Teologi Pastoral
}

\author{
Alvian Apriano \\ Vikaris Gereja Protestan di Indonesia bagian Barat (GPIB) \\ alviapriano@gmail.com
}

\begin{abstract}
Pastoral care ministry persists in the minister's concept as the sole actor of pastoral ministry in the church. On the other hand, there has been growing awareness that pastoral care ministry also gives space to members of the congregation to presenting the pastoral care ministry in context. In these persist circumstances, questions arise is how do pastoral care ministry gives space to members? Can the paradigm be expanded by taking into account the communal context? What kind of model does it produce? With the development of a communal-contextual paradigm in pastoral theology began to raise awareness of expanding that understanding. In addition, contemporary pastoral theologians show that there has been a paradigm shift in pastoral ministry with communal nuance; however, the ministry also gives space to the members of the congregation in practice. My aim is to construct the concept and model of pastoral care ministry with the community within the framework of communal-contextual paradigm.
\end{abstract}

\begin{abstract}
Abstrak
Diskusi pelayanan pastoral dalam teologi pastoral bertahan dalam konsep pendeta sebagai aktor tunggal pelayanan tersebut di dalam gereja hampir tiga dekade belakangan ini. Padahal, di sisi yang lain, sudah muncul dan berkembang paradigma bahwa pelayanan pastoral juga tentang pemberian ruang terhadap anggota jemaat secara umum yang hadir dalam pelayanan pendeta dalam konteksnya. Di dalam keadaan ini, muncullah pertanyaanpertanyaan tentang apakah pelayanan pastoral hanya merupakan tugas seorang pendeta? Dapatkah paradigma tersebut diperluas dengan memperhatikan konteks pelayanan yang nilai komunalitasnya tinggi? Seperti apa model yang dihasilkannya? Dengan berkembangnya paradigma komunal-kontekstual dalam pelayanan pastoral mulai muncul kesadaran memperluas pemahaman itu. Di tambah lagi, pemikiran teolog pastoral kontemporer baik dari Indonesia dan Barat juga menunjukkan bahwa telah ada pergeseran paradigma tentang pelayanan pastoral yang bernuansa komunalitas di dalam suatu konteks, sehingga pelayanan tersebut juga memposisikan anggota jemaat secara umum. Penelitian ini berupaya menawarkan konsep dan model pelayanan pastoral yang kontekstual dengan menempatkan partisipasi komunitas guna memberi warna lain bagi pelayanan pastoral yang selama ini bertahan.
\end{abstract}

Article History

Submit:

07 July 2018

Revised:

20 October 2018

Accept:

27 October 2018

Keywords:

pastoral care ministry; minister; communal-contextual paradigm; members of conggregation, model of pastoral care ministry

Kata kunci: pelayanan pastoral; pendeta; paradigma komunal-kontekstual; model pelayanan pastoral; pelayanan bersama komunitas 


\section{Pendahuluan}

Sejak pelayanan pastoral didefinisikan sebagai tugas dan tanggung jawab pendeta, gereja-gereja sebagai wadah pelayanan pastoral mengorganisasi pelayanannya dengan penekanan kepada pelayanan seorang pendeta. Hal ini membangun paradigma bahwa pelayanan pastoral adalah suatu pelayanan pendeta terhadap jemaat yang bermasalah dan perlu solusi atas masalahnya. Pusat pelayanan ini adalah pendeta, dan objek pelayanan ini adalah jemaat. Di dalam istilah Charles Gerkin, teolog pastoral, seorang pendeta seakan-akan terseret ke dalam arus pelayanan terhadap masalah anggota jemaat, sehingga yang didekati hanyalah literatur-literatur psikologis-psikoterapis sendirian, tanpa berkolaborasi dengan "another living human document" atas permasalahan yang tengah dialami oleh jemaatnya. ${ }^{1}$

Di sisi yang lain, Scott Douglas, pemerhati pendampingan pastoral, mengutarakan bahwa pendeta di dalam proses pengorganisasian jemaatnya, rentan dengan pelbagai aktivitas yang dapat membuatnya kehilangan fungsi pengawasan. Padahal, fungsi inilah yang membuat pelayanan pastoral menunjukkan relevansi dan implikasinya di dalam kehidupan ministerial. Douglas melihat ada peluang untuk menambal fungsi pengawasan yang rentan itu dengan memperlengkapi anggota jemaat "for the work of ministry". 2 Dengan begitu, pelayanan pastoral dan tentunya pelayanan pendeta memperkaya keterampilan anggota jemaat dalam proses pengalaman bergereja mereka.

Berdasarkan kegelisahan Gerkin dan Douglas atas bertahannya paradigma pelayanan pastoral yang demikian, muncul pertanyaan tentang apakah pelayanan pastoral hanya melulu pendeta dan bagaimana ia secara pribadi menghidupi pelayanan tersebut? Bagaimana dengan anggota jemaat yang juga hadir di dalam panggilan pendeta untuk menghidupi pelayanan tersebut? Pertanyaan ini membawa kita untuk masuk ke dalam kerangka berpikir di bawah upaya mengembangkan sebuah model pelayanan pastoral yang memberi ruang bagi anggota jemaat, karena anggota jemaat yang hadir dalam pelayanan pendeta dan sedikit banyak mengetahui masalah yang dialami oleh jemaat yang memiliki masalah tersebut.

Memang, jika melihat konteks Indonesia yang nilai komunalitasnya kental, maka dapat dikembangkan suatu model pelayanan pastoral berbasis komunitas. Misalnya, dalam relasi nasional bangsa ini menghidupi nilai musyawarah mufakat dan gotong royong yang penekanannya ialah partisipasi dan kolaborasi antarpribadi. Sementara itu, pelayanan berbasis

\footnotetext{
9-11

${ }^{1}$ Gerkin, Charles. Konseling Pastoral dalam Transisi, terj. Adji Sutama. (Kanisius: Yogyakarta, 1992),

${ }^{2}$ Douglas, Scott. "Developing Leaders for Pastoral Ministry," Journal of Applied Christian Leadership; Vol. 8, No. 2 (2014), 84-90.
} 
komunitas setepatnya merupakan suatu realisasi dari perkembangan paradigma komunalkontekstual dalam diskusi teologi pastoral yang dapat dipahami sebagai suatu bentuk perhatian dan kepedulian kepada seseorang yang dilakukan dalam konteks pelayanan gerejawi.

Dengan berkembangnya paradigma komunal-kontekstual dalam teologi pastoral, relasionalitas di dalam pelayanan pastoral semakin jelas ke permukaan. Terlebih saat aspek komunalitas juga menjadi penekanan. Penelitian ini merupakan sebuah upaya menyajikkan model pelayanan pastoral berbasis komunitas, sebagai langkah partisipatif dalam pengembangan berteologi pastoral kontekstual di Indonesia. Pendekatan yang digunakan ialah menelusuri paradigma komunal-kontekstual yang tengah berkembang dalam teologi pastoral. Akhirnya, model berteologi pastoral yang bernuansa komunitas akan dikonstruksi, sehingga akan ditawarkan juga beberapa model pelayanan pastoral sebagai saran kontekstual.

\section{Kritik Paradigma Pelayanan Pastoral sebagai Pelayanan Pendeta}

Pada umumnya, di dalam rangka mewujudkan eksistensinya secara dekat, gereja senantiasa hadir melalui pelayanan pastoral yang dilakukan pendeta. Polarisasi umum ini menciptakan pandangan bahwa pelayanan pastoral hanyalah tentang pendeta dan di luar pendeta tidak ada yang dirasa kompeten melakukan pelayanan pastoral. Memang, pendeta merupakan faktor penggerak utama di dalam praktik pelayanan pastoral. Akan tetapi, dapatkah kolaborasi tercipta di dalam pelayanan pastoral, sehingga-meminjam istilah Douglas-for the work of ministry-nya pendeta juga melibatkan anggota jemaatnya. Di tengah-tengah pergumulan itu, muncullah pertanyaan praktis yang perlu untuk dijawab secara teologis, yakni seberapa signifikan komunitas - di dalam hal ini anggota jemaat-yang di dalamnya pendeta hadir melayani diberi ruang untuk melayani bersama? Bukankah komunitas juga dapat menjadi faktor penggerak berikutnya dalam menjalankan pelayanan pastoral bersama pendeta?

Berkenaan dengan itu, kita perlu berangkat dari perspektif J. L. Ch. Abineno, teolog pastoral Indonesia yang banyak sekali berurusan dengan karya-karya teologi pastoral yang diduga cenderung mengakarkan teologi pastoral, karena definisi yang melekatkan bahwa tugas itu kepada pendeta. ${ }^{3}$ Padahal, pandangan Abineno tentang pelayan-pelayan pastoral itu juga melibatkan keberadaan anggota-anggota jemaat umum. Ia membahasnya dalam konteks siapakah pelaku pastoral dalam konteks pelayanan. Baginya pelayanan itu dilangsungkan oleh

\footnotetext{
${ }^{3}$ J. L. Ch. Abineno, Percakapan Pastoral dalam Praktik, (Jakarta: BPK Gunung Mulia, 1982), 12
} 
“jemaat dalam arti umum dan oleh pastor (pendeta) (pejabat-pejabat khusus dan anggotaanggota jemaat) secara khusus". 4

Bahkan, telah ditegaskan dalam buku berjudul Jemaat, bahwa jemaat adalah orangorang yang dipilih dan ditetapkan oleh Yesus Kristus melalui keberadaan jemaat untuk memimpin, mengajar, dan menggembalakan jemaat. ${ }^{5}$ Menurutnya, pelayan khusus ini ditetapkan bukan karena mereka memiliki jabatan istimewa dibandingkan dengan yang lain, melainkan sebagai anggota-anggota jemaat mereka diperkenankan oleh Yesus Kristus sendiri sebagai Kepala Gereja untuk melayani Dia di dalam jemaat-Nya. ${ }^{6}$ Dengan begitu, posisi pelayanan khusus itu sama dengan anggota-anggota jemaat pada umumnya. Abineno sebetulnya telah memelopori pergeseran paradigma tentang pelaku pastoral dalam gereja menjadi lebih leluasa, sehingga Abineno berpihak dalam paradigma kolaboratif dalam proses pelayanan dan persekutuan di gereja, khususnya pelayanan pastoral.

Ternyata, pergumulan tentang terbatasnya paradigma pelayanan pastoral yang berarti pelayanan pendeta juga disadari oleh Daniel Susanto dosen teologi pastoral dan pendampingan pastoral di Sekolah Tinggi Teologi Cipanas, bahwa masih dominan juga paradigma itu di masa kini. Di dalam kumpulan tulisan berjudul Sekilas Pelayanan Pastoral di Indonesia, bersama beberapa kontributor yang seluruhnya berstatus pendeta, ia menegaskan pentingnya pencarian model pelayanan pastoral yang kontekstual di Indonesia yang tidak tradisional. Baginya, pelayanan pastoral yang dilakukan gereja-gereja kita di Indonesia pada masa kini, dapat dikatakan sempit dan terbatas. Sempit, karena masih bersifat ekslusif dan teraplikasi hanya secara internal gereja. ${ }^{7}$

Susanto kemudian menguraikan tiga faktor yang utamanya berkenaan dengan pemahaman tentang pelayanan pastoral di Indonesia yang sempit dan terbatas tersebut. Pertama, pemahaman tentang pelayanan pastoral di Indonesia diwarisi dari Barat dan belum dikembangkan sesuai dengan konteks Indonesia. Pelayanan pastoral yang diwarisi dari Barat mula-mula lebih mengarah ke dalam dan bersifat individualistis, dan merupakan tugas pendeta. Kedua, pelayanan pastoral di Indonesia masih didasarkan pada gambaran gembala dan domba pada masyarakat agraris, seperti yang terdapat dalam beberapa bagian dari

\footnotetext{
${ }^{4}$ J. L. Ch. Abineno, Pedoman Praktis untuk Pelayanan Pastoral, cet. ke-2, (Jakarta: BPK Gunung Mulia, 1999), 12

${ }^{5}$ J. L. Ch Abineno, Jemaat. (Jakarta: BPK Gunung Mulia, 1987), 149

${ }^{6}$ Ibid., 150

${ }^{7}$ Daniel Susanto, “Dalam Sekilas tentang Pelayanan Pastoral di Indonesia,” Pelayanan Pastoral Holistik, peny. Daniel Susanto, Jakarta: Majelis Jemaat GKI Menteng, 2010.
} 
Alkitab. ${ }^{8}$ Ketiga, pelayanan pastoral di Indonesia masih mengikuti pembagian pelayanan gereja secara tradisional, sehingga pelayanan pastoral masih dianggap sebagai salah satu jenis pelayanan di gereja. ${ }^{9}$

Hampir senada dengan pencarian model pelayanan pastoral yang relevan di dalam konteks tersebut, Besly Messakh, pengajar teologi pastoral di Sekolah Tinggi Filsafat Teologi Jakarta, dengan mengutip Clebsch dan Jaekle mengatakan bahwa pelayanan pastoral yang subjeknya merupakan orang-orang yang bermasalah tidak hanya terbatas dilakukan para pendeta, tetapi juga oleh orang-orang Kristen yang representatif. Hal ini asalkan sejalan dengan fungsi pemulihan, topangan, bimbingan, dan pendamaian. Menurut Messakh, orangorang seperti ini bisa saja seorang penatua, pelayan, pendeta, majelis, bishop, diaken, dan orang lainnya yang mampu melaksanakan tugas tersebut. ${ }^{10}$

Dari Abineno, Susanto dan Messakh kita telah diperlihatkan bahwa pencarian model pelayanan pastoral yang relevan di dalam konteks gereja kita masih sangat diperlukan melihat dominasi pemikiran pendeta sebagai pusat dalam pemahaman teologi pastoral di Indonesia. Sebuah poin yang signifikan dan perlu kita catat dari uraian Susanto ialah bahwa pelayanan pastoral itu masih bersifat aktivitas individual. Semua menjadi serba pendeta, tanpa pendeta di sebuah jemaat maka pelayanan pastoral belum dapat diukur aktivitasnya, sehingga pertanyaan yang muncul ialah bagaimana dengan gereja yang tidak memiliki pendeta tetap? Oleh karena itu, sudah waktunya untuk mengembangkan model-model pelayanan pastoral dalam konteks Indonesia yang nilai komunalitasnya tinggi dengan memberi ruang juga bagi komunitas dalam menjalankan pelayanan tersebut.

Bercermin dari ketiga perspektif mereka, terlihat bahwa pencarian model pelayanan pastoral adalah suatu proses berteologi pastoral yang tidak pernah usai. Ketiganya, agaknya menerjemahkan pelayanan pastoral dari kata pastoral care ministry, dan bukan pastoral ministry, karena nuansa karya bersama tersebut lebih kepada pelayanan pendampingan pastoral. Oleh karena itu, di dalam makalah ini, kita akan secara konsisten memaksudkan pengertian pelayanan pastoral yang merupakan terjemahan ilmiah dari pastoral care ministry. Pertanyaan mendasar yang berkenaan dengan pencarian model di sini ialah sejauh manakah pergeseran definisi itu terjadi dalam lingkup teologi pastoral?

${ }^{8}$ Bagian-bagian Alkitab yang memuat tentang gambaran itu (misalnya: Yesaya 40:11, Mazmur 23, Yehezkiel 34, dan Yohanes 10) ditafsirkan secara tradisional dan terbatas, di mana domba-domba hanya dimengerti sebagai orang-orang percaya atau anggota gereja yang mesti dilegakan.

${ }^{9}$ Ibid.

${ }^{10}$ Besly Messakh, "Menuju Pelayanan Pastoral yang Relevan dan Kontekstual,” Jurnal Theologia in Loco; Vol. 1, No. 1, (2018); 22-40. 


\section{Pergeseran Definisi Pelayanan Pastoral}

Sebelumnya telah dimunculkan pembatasan definisi, dan pertanyaan-pertanyaan kritis seputar kajian model. Di bagian ini adalah investigasi atas pertanyaan yang sebelumnya diajukan itu. Di dalam tujuan itu, pertama-tama penting bagi kita untuk meninjau pengertian umum perkamusan tentang pelayanan pastoral itu sendiri, dan kemudian memperbandingkannya dengan pengertian dari para teolog pastoral kontemporer guna menjawab pertanyaan tersebut.

Kita tidak dapat memungkiri bahwa pelayanan pastoral memiliki banyak pengertian dan terejawantah ke dalam berbagai bentuk. Di sini, kita akan memberikan analisis dan kritik atas definisi pelayanan pastoral yang bertahan dalam paradigma kerja pendeta seorang. Menurut Encylopedia of Bioethics, pelayanan pastoral "normally refers to the help given by ordained ministers, priests, and other persons with designated religious roles (such as deacons and members of Roman Catholic religious orders) to suffering, troubled, or perplexed persons." $" 11$ Dua tujuan utama tersebut secara terang-terangan memperlihatkan bahwa pelayanan pastoral dalam definisi jenis ini ialah tentang mewadahi pertolongan, mendampingi, memberikan motivasi verbal agar kasih Allah nyata dalam hidup seseorang. Perannya pun tetap, yakni para pelayan berstatus tahbisan (pendeta dan majelis jemaat).

Sementara itu, menurut Dictionary of Pastoral Care and Counseling, pelayanan pastoral "derives from the biblical image of shepherd and refers to solicitious concern expressed within religious community for persons in trouble distress. Historically, and within Christian community, pastoral care is in the cure-of-soul tradition." ${ }^{12}$ Cure of soul yang dimaksudkan di sini ialah "in the sense of carefulness or anxious concern, not necessarily as healing, for the soul, i.e. the animating center of personal life and the seat of relatedness. ${ }^{13}$

Dari dua definisi ini kita melihat adanya konsistensi bahwa pelayanan pastoral ialah tugas gembala yang sebagai penyembuhan jiwa, dan peduli, agar kehadirannya menghidupi kehidupan umat yang kesusahan. Dari dua definisi perkamusan tersebut, kita melihat bahwa kunci sukses aktivitas pelayanan pastoral ada pada gerak gembala atau pelayan tahbisan lainnya. Meskipun demikian, definisi itu menunjukkan kelemahannya. Kelemahan dari pandangan ini ialah pelayanan pastoral menjadi sangat privat, sehingga ukuran dari relevan

\footnotetext{
${ }^{11}$ Warren Riech, peny. 1995. Encyclopedia of Bioethics, New York: Simon \& Schuster, s.v. Pastoral Care (Rodney J. Hunter).

${ }^{12}$ Rodney J. Hunter, peny. Dictionary of Pastoral Care and Counseling, Nashville: Abingdon Press, s.v. Pastoral Care (L. O. Mills), 1990

${ }^{13}$ Ibid.
} 
atau tidaknya pelayanan jenis itu menjadi pertanyaan, karena tidak mengakomodasi sebagai referensi lainnya dari subjek pastoral. ${ }^{14}$

Memang, definisi yang seperti tersebut di atas, berangkat dari pemahaman tentang tahbisan yang melakukan pelayanan pastoral sebagaimana dipahami bahwa tahbisan adalah akta kudus perjanjian kesetiaan untuk melayani Tuhan secara sepenuh. ${ }^{15}$ Akan tetapi, pertanyaan yang muncul dari definisi yang bertahan demikian ialah apakah pendeta atau gembala, atau yang tertahbis itu tidak memiliki masalah, sehingga ia tidak perlu dilayani secara pastoral? Siapakah yang dapat melayani mereka dalam pergumulannya? Apakah hanya sebatas tahbisan lain? Atau adakah peluang partisipatif dari umat yang sering kali dilayaninya itu untuk juga mewarnai pelayanan pastoral?

Di dalam menjawab pertanyaan-pertanyaan tersebut, kita akan menelusuri sebuah paradigma yang cenderung baru dalam pelayanan pastoral, yakni paradigma komunalkontekstual. Paradigma ini berkembang dengan melihat kelemahan dari paradigma yang dibangun secara definitif kamus-kamus sebelumnya. Di dalamnya, terdapat peluang bagi siapapun di dalam gereja untuk terlibat dalam pelayanan pastoral $^{16}$, berangkat dari kegelisahan atas pertanyaan-pertanyaan tersebut. Hal ini tetap mendorong kualitas pendeta sebagai pemandu tetapi tidak mengintervensi pelayanan tersebut secara leluasa, seperti yang juga telah diperlihatkan oleh kedua definisi leksikal sebelumnya.

Pergeseran ini telah ditinjau mula-mula oleh Seward Hiltner yang menegaskan bahwa orang-orang yang dapat terlibat dalam pelayanan pastoral tidak hanya terbatas pada jabatan tahbis pendeta saja, tetapi juga jemaat yang bersamanya pendeta melakukan tugas pelayanannya. Meskipun demikian, ia tidak sampai sedemikian ekstrem dengan menyatakan bahwa porsi tanggung jawab pendeta menjadi sedikit berkurang, melainkan pendeta tetap memiliki kewajiban yang lebih besar ketimbang jemaat di dalam pelayanan ini. ${ }^{17}$

Berangkat atas dasar pergeseran tersebut, pandangan yang cenderung baru juga dimunculkan oleh Margaret Whipp, seorang pengajar studi pastoral di Ripon College Cuddesdon, Amerika Serikat. Ia menyatakan bahwa "pastoral care is always about growing together."18 Dengan demikian, standar pelayanan pastoral bukanlah tentang tugas pelayanan pendeta, tetapi tentang bagaimana bertumbuh secara bersama (komunal). Polanya agak

\footnotetext{
${ }^{14}$ Edward Morgan, "Implication of the Masculine and the Feminine in Pastoral Ministry," The Journal of Pastoral Care; Vol. XXXIV, No. 4, (1980); 268-277.

${ }^{15}$ Michael Horton, Introducing Covenant Theology, Grand Rapids: Baker Book Publishing, 2009.

${ }^{16}$ Harls Evan R. Siahaan, “Aktualisasi Pelayanan Karunia Di Era Digital,” EPIGRAPHE: Jurnal Teologi dan Pelayanan Kristiani 1, no. 1 (2017): 23-38, www.stttorsina.ac.id/jurnal/index.php/epigraphe.

${ }^{17}$ Seward Hiltner, Preface to Pastoral Theology, (Nashville: Abingdon Press, 1958), 3-4

${ }^{18}$ Margareth Whipp, Pastoral Theology, (London: SCM Press., 2013), 86
} 
berbeda dengan definisi sebelumnya. Di sini, ia mulai menjelaskan pelayanan pastoral dengan penekanan terhadap aspek dinamisnya komunitas, yakni anggota jemaat awam dalam sebuah gereja itu sendiri.

Latar belakangnya sebagai seorang pendeta rumah sakit membuatnya tidak dapat memungkiri bahwa pelayanan tersebut tetap membutuhkan pendeta, karena peran pendeta berkaitan dengan pola relasi dan ritual yang dilaksanakan dalam pelayanan pastoral. ${ }^{19}$ Akan tetapi, Whipp menggeser paradigma pelayanan pastoral bahwa pelayanan ini tidak melulu terjadi hanya karena pendeta. Pergeseran paradigma ini dialami Whipp, karena ia mengamati bahwa dalam konteks rumah sakit siapapun ialah pelayan pastoral, karena dasar melayani "si sakit" adalah kepedulian terhadap mereka. ${ }^{20}$

Lebih jauh lagi, Whipp menekankan eratnya kaitan antara pelayanan pastoral dan teologi panggilan Allah. Definisi ini menambah wawasan kita dalam pencarian model pastoral berbasis nilai komunal. Menurutnya, pelayanan pastoral juga berkaitan dengan panggilan Allah bahwa umat percaya hidup dan bertumbuh bersama dalam komunitas. Teladannya adalah rasul Paulus yang menekankan prinsip hidup umat Kristen sebagai komunitas bersama (Kol.2:19; Ef.4:16). Teologi Paulus tentang Tubuh Kristus menjadi fondasi iman mendasar ketika mempercakapkan tentang komunitas sebagai basis pelayanan pastoral. Lebih jauh, Tubuh Kristus itu menerima siapapun dari latar belakang, suku apapun ke dalam gereja, dan pelayanan jenis apapun. Dengan demikian, umat dipanggil untuk mengejawantahkan-Nya. ${ }^{21}$

Bahkan, panggilan umat Kristiani adalah berpartisipasi dalam persekutuan dan menciptakan ruang relasi yang mutual dengan yang lain, dan melalui perjumpaan itu, Roh Kudus bekerja dalam pertumbuhan iman. Di sini ia menggunakan istilah pelayan pastoral. Baginya pelayan pastoral tidak melulu pendeta, tetapi ketika umat terpanggil dengan itu ialah juga pelayan pastoral itu sendiri. ${ }^{22}$ Jangkauannya tidak hanya tentang di dalam, tetapi lebih ke luar. Bahkan ia menyebut istilah "fresh expressions of Churh," ketika gereja nyata hadir ke ranah sosial, bahkan dan politik. ${ }^{23}$

Bahkan, Catherine Faith MacLean, pegiat pelayanan pastoral yang memahami pelayanan pastoral dari perspektif pastoral ministry menegaskan bahwa "we are all concerned about renewal of persons, congregations, communities, and the world. What a privilege to

\footnotetext{
${ }^{19}$ Ibid.

${ }^{20}$ Ibid., 9-10

${ }^{21}$ Ibid., 86

${ }^{22}$ Kevin Tonny Rey, "Konstruksi Teologi Dalam Konteks Reposisi Pemikiran Warga Gereja," EPIGRAPHE: Jurnal Teologi dan Pelayanan Kristiani 2, no. 1 (2018): 1-13, www.stttorsina.ac.id/jurnal/index.php/epigraphe.

${ }^{23}$ Ibid., 89
} 
witness those transformations when we show up."24 Ia menarik cakupan dari pelayanan pastoral yang tidak hanya tentang pelayanan pendeta, tetapi pelayanan yang secara menyeluruh dilakukan oleh setiap elemen dalam jemaat.

Poin tersebutlah yang penting dalam upaya kita menawarkan suatu model pelayanan pastoral di gereja masa kini. Bercermin dari realitas gereja-gereja di Indonesia yang setiap hari Minggu masih hampir didatangi umat untuk beribadah (bahkan akan terus meningkat), paradigma ini akan dapat menyadarkan gereja-gereja untuk mengundang dan menjadikan kehadiran umat berkualitas dengan berpartisipasi aktif melalui pelayanan pastoral.

Pada akhirnya, kita telah melihat bahwa poros pelayanan pastoral kini tidak melulu pendeta sebagai aktor penggerak (individual), tetapi adanya peluang bagi komunitas untuk menggerakan (komunal) pelayanan pastoral. Beberapa definisi yang kita pakai dalam penelitian ini memperlihatkan sejauh mana pergeseran pengertian tentang teologi pastoral itu sendiri. Akan tetapi, kita tidak dapat memungkiri bahwa peran pendeta tetap dibutuhkan didalamnya. Oleh karena itu, di dalam hal ini kita memerlukan suatu model pelayanan pastoral dalam paradigma komunal, namun tetap menjaga kehadiran peran pendeta.

\section{Metodologi}

Ini merupakan penelitian kualitatif dengan pendekatan literatur, menggunakan metode deskriptif. Penulis memberikan gambaran tentang pelayanan pastoral melalui beberapa pendapat ahli di bidangnya, dengan literatur yang berkaitan dengan teologi pastoral. Penggunaan literatur untuk menemukan definisi tentang teologi atau pelayanan pastoral dalam konteks kini dan mempertimbangkan model pelayanan komunal sebagai sebuah dimensi dalam pelayanan pastoral.

\section{Pembahasan}

\section{Paradigma Komunal-Kontekstual dalam Pelayanan Pastoral}

Sebelum menelusuri apa itu paradigma komunal-kontekstual dan bagaimana keterkaitannya dengan pelayanan pastoral, kita perlu mengetahui latar belakang munculnya paradigma komunal itu sendiri. Didalamnya, kita perlu meninjau pemikiran John Patton yang secara fokus memperkaya paradigma komunal dan bentuk komunalitas dalam pelayanan pastoral.

Menurut Patton, dalam buku berjudul Pastoral Care in Context: An Introduction to Pastoral Care, paradigma komunal-kontekstual muncul ketika tiga puluh tahun terakhir

\footnotetext{
${ }^{24}$ Catherine MacLean, “Showing Up: The Essential Practice of Pastoral Care,” Touchstone Journal,
} 
berkenaan dengan semangat ekumenis yang baru ditunjukkan oleh Konsili Vatikan II dan Konsultasi dalam Church Union. Keduanya, Gereja Katolik Roma dan Gereja-gereja Protestan, telah menggeser otoritas gerejawi dari hirarki pelayan tahbisan ke komunitas Kristen secara umum. Hal ini telah lebih jauh mengembangkan gerakan-gerakan pembebasan terhadap keterhimpitan ekonomi, ras, jender, dan sebagainya. ${ }^{25}$ Arah teologi pastoral kemudian berkembang mencakup realitas sosial kemanusiaan sebagai aksi atas ide "konteks" tersebut.

Patton sebetulnya, membubuhi kata kontekstual untuk menunjukkan pentingnya menamai permasalahan yang secara konkret dihadapi, sehingga istilahnya menjadi communalcontextual paradigm. Akan tetapi, apabila diterjemahkan setelah mendalami Patton, makna yang dihasilkan ialah suatu paradigma pelayanan pastoral di dalam suatu konteks. Konteks yang dimaksudkan di situ ialah realitas sosial maupun gereja. ${ }^{26}$ Dengan demikian, paradigma ini tetap memberi penekanan terhadap komunalitas, sehingga saya menggunakan istilah paradigma komunal saja, karenanya menjadi lebih eksplisit, tanpa menghilangkan nilai penting bahwa pelayanan ini perlu berlandaskan konteks tertentu.

Dari definisi utama yang telah Patton utarakan, kita telah melihat bahwa paradigma komunal memperluas fokus pelayanan pastoral yang tidak hanya tentang karya para pendeta, melainkan juga karya anggota jemaat. Patton memang tidak secara langsung menyatakan bahwa pelayanan pastoral jenis ini tidak lagi memerlukan peran dari pendeta, tetapi membuka ruang yang cukup bagi anggota jemaat untuk ambil bagian dalam pelayanan pastoral. Dengan demikian, terjalin kerjasama yang simetris antara para pelayan tahbisan dan anggota jemaat awam.

Landasan praktisnya tetap, yakni membawa dan memberikan pesan kepedulian. Akan tetapi, pertanyaan yang muncul ialah apa yang mendasari Patton untuk sampai kepada paradigma ini? Pertanyaan ini perlu dijawab, karena Patton menciptakan pergeseran yang cukup signifikan apabila kita kembali ke istilah perkamusan tentang pelayanan pastoral sebelumnya.

Ternyata, Patton sampai kepada paradigma ini, karena berkaca dari respons reaktif Natalie, salah satu anggota kelompok lay minister di gereja Presbiterian Southwest yang merupakan anggota gereja tersebut sejak lama. Natalie bertumbuh tanpa Ayah. Ayahnya telah meninggal sejak ia kecil. Pada suatu kali, Patton pernah menyampaikan pembinaan tentang

\footnotetext{
${ }^{25}$ John Patton, Pastoral Care in Context: An Introduction to Pastoral Care, (Louisville: Westminster, 1993), 4-5.

${ }^{26}$ Ibid., 6-7
} 
memaknai komunitas dalam kaitannya dengan pelayanan pastoral gereja. Didalamnya, Natalie hadir. Natalie tersentuh materi Patton, karena komunitas menjadi sesuatu yang penting, yang hadir dalam kehidupannya secara nyata, sejak pasca kehilangan Ayahnya. ${ }^{27}$ Dengan demikian, Patton melihat komunitas dapat menjadi daya pastoral yang kuat dalam satu kehidupan bergereja.

Secara teologis, paradigma komunal ini telah merepresentasikan tradisi alkitabiah tentang Allah yang peduli, dan memilih orang-orang percaya dalam komunitasnya untuk merayakan kepedulian dan menjadi perpanjangan pesan kepedulian. ${ }^{28}$ Kita familiar dengan teologi umat pilihan Allah, yakni Israel. Israel diutus Allah untuk menjadi perpanjangan tangan-Nya. ${ }^{29}$ Juga, pelayanan pastoral yang membuka ruang dan melibatkan kolaborasi dengan komunitas (anggota jemaat) yang hadir di dalam tugas dan pelayanan pendeta menandai relasi Trinitarian melalui relasi yang terjalin antar-sesama pelayan yang Allah di dalam gerak komunitas iman sebagai komunitas yang melayani. ${ }^{30}$ Demikian halnya dengan pelayanan pastoral jenis ini. Allah mengutus anggota jemaat, umat pilihannya yang partikular masa kini ${ }^{31}$ untuk menjadi perpanjangan kepedulian Allah melalui keterlibatan mereka dalam pelayanan pastoral.

Porsi teologis yang direfleksikan oleh Patton sebelumnya, memunculkan pertanyaan penting tentang "komunitas seperti apakah yang dapat menjadi perpanjangan kepedulian Allah dalam pelayanan pastoral?" Bagi Patton-meminjam definisi William Willimonkomunitas yang diperlukan ialah komunitas yang memiliki identitas, otoritas, visi, berbagi hidup bersama. ${ }^{32}$ Dengan demikian, Patton menambahkan wawasan yang penting dalam pencarian kita, yakni pelayanan pastoral itu tumbuh dari mutualitas kepedulian sehingga memungkinkan mereka yang mengalami masalah menerima kepedulian dan mengalami "rasa" komunitas itu sendiri.

Mereka yang kita dimaksud di sini menjadi sangat komunal, sebagaimana Barbara McClure utarakan secara khusus dalam Moving Beyond Individualism In Pastoral Care And Counseling. Perspektifnya cenderung baru dan memperlengkapi paradigma komunal dalam pelayanan pastoral, karena konsekuensi konteks sosial dengan permasalahan-permasalahan yang khas, sehingga memerlukan perspektif yang juga khas dan tidak melulu perspektif

\footnotetext{
${ }^{27}$ Ibid., 20-21

${ }^{28}$ Ibid., 15-16

${ }^{29}$ Horton, Introducing Covenant Theology, 31-32

${ }^{30}$ Kwon, Soo-Young. "Codependence and Interdependence: Cross-Cultural Reappraisal of Boundaries," Journal Pastoral Psychology, Vol. 50, No. 1 (2001); 39-52.

${ }^{31}$ Horton, Introducing Covenant Theology, 129

${ }^{32}$ Patton, Pastoral Care in Context: An Introduction to Pastoral Care, 21-22
} 
pendeta. ${ }^{33}$ Di dalam perkataan lain, pelayanan pastoral juga mengarah kepada dimensi eksternal tidak hanya tentang internal, yakni bagian jiwa jemaat yang perlu diatasi oleh pendeta, melainkan juga pelayanan pendeta bersama jemaat yang punya perspektif khas atas konteks dan masalah sosial, sehingga tujuan pelayanan pastoral itu terjawab.

Jelas bahwa paradigma komunal tersebut menjadi relevan karena selalu disertai dengan cakupan kontekstual. Menurut Karen Scheib, seorang praktisi pastoral di jemaat yang mengembangkan model "Care Team" dalam pelayanannya paradigma tersebut "reflects a development in the field of pastoral care, the emergence of the communal-contextual model of care, in which pastoral care is understood as the responsibility of the entire congregation". ${ }^{34}$ Ia mengkritik kecenderungan pastoral yang bersifat klinis, sehingga melanggengkan "clerical hegemony of classical and clinical models". 35 Dengan demikian, kita perlu sampai kepada model seperti apakah yang akan kita tawarkan.

\section{Pelayanan Bersama Komunitas: Pelayanan Pastoral berbasis Paradigma Komunal}

Deskripsi dan analisis kita telah menunjukkan bahwa pelayanan pastoral memiliki kecenderungan komunal. Problemnya adalah dari manakah ukuran perilaku komunitas tersebut? Kita telah melihat bahwa definisi-definisi yang telah dimunculkan memperlihatkan pentingnya faktor pendeta sebagai aktor dari pelayanan pastoral tersebut. Secara teologis, iman pendeta yang disepadankan dengan analogi gembala dalam Alkitab menjadi faktor utama minimnya pelayanan pastoral berbasis komunitas. Oleh karena itu, ukuran komunitas pastoral yang akan kita tawarkan harus tetap berdasarkan aspek imaniah.

Dari masalah yang telah kita simak di bagian pendahuluan kita melihat peluang yang besar untuk mengembangkan suatu model pelayanan pastoral yang memiliki rasa Indonesia, yakni bernuansa komunitas. Pengembangan model ini kita temukan melalui beberapa pemikir pelayanan pastoral yang telah menggeser paradigma itu ke arah yang lebih bersifat kolaboratif sehingga memberi ruang bagi komunitas. Oleh karena itu, Whipp memperlihatkan kepada kita kualitas dari aspek komunalitas dalam pelayanan pastoral, namun tetap memberi ruang bagi pendeta. Sementara itu, Patton mendorong kita untuk mengembangkan pelayanan pastoral berbasis komunitas yang mengarah kepada ketetapan konteks masing-masing. Beberapa pemikir pastoral ini, secara nyata membuka ruang bagi kita untuk menamai model tersebut.

\footnotetext{
${ }^{33}$ McClure, Barbara. Moving Beyond Individualism in Pastoral Care and Counseling: Reflections on theory, theology and practice, (Oregon: Cascade Book, 2010), 4-5

${ }^{34}$ Karen Scheib, "Contributions of Communion Ecclesiology To The Communal-Contextual Model of Care,” The Journal of Pastoral Theology: Vol. 12, No. 2 (2002); 28-50.

${ }^{35}$ Ibid.
} 
Di sini, dengan berangkat dari analisis dan elaborasi dari paragidma yang dibangun dalam penelitian ini, model tersebut bernama "Pelayanan bersama Komunitas" yang memiliki landasan pelayanan, dengan tetap bertumpu pada istilah care dalam pastoral care ministry itu sendiri. Namun demikian, nilai care-nya dalam pengertian yang mendalam. Di sini, kita memanfaatkan Ronald Edwin Hughes dalam disertasi doktoral bidang studi pastoral di Liberty University Baptist Theological Seminary tentang model pelayanan pastoral berbasis C.A.R.E yang cenderung baru. Di sini, kata C.A.R.E tersebut mesti dimaknai sebagai pelayanan. Pemikirannya menjadi menarik ketika ia memaknai care sebagai akronim. Menurutnya, akronim dari care ialah (C)ounsel, (A)ffirm, (R)esource, (E)quip. ${ }^{36}$

Akronimnya menjadi bernilai pastoral ketika ia menjelaskannya. Pertama adalah Counsel. Counsel merupakan proses mendampingi dalam rupa pemberian nasihat atas peristiwa-peristiwa kehidupan yang telah terjadi. Kita dapat menerjemahkannya dengan konseling. Konseling ini mencakup, anggota jemaat awam, pelayan tahbisan, termasuk pendeta. ${ }^{37}$ Komunitas menjangkau orang yang sedang mengalami krisis identitas, terkena disiplin gereja, dan suatu kelompok organisasi sosial yang sedang konflik atas masa lalu. ${ }^{38}$ Bagi kelompok yang sedang konflik, jenis pendampingan sebagai mediator, sedangkan bagi yang mengalami krisis rohani dan disiplin gereja, jenis pendampingannya sebagai pendengar.

Kedua adalah Affirm. Affirm adalah proses kesediaan memberi kenyamanan dan dukungan dalam cobaan-cobaan kehidupan. Kita dapat menerjemahkannya dengan penguatan. Komunitas menjangkau mereka yang berduka, sakit dan dirawat inap, serta yang terhimpit secara ekonomi. ${ }^{39}$ Bentuknya dapat berupa liturgi doa dan pelayanan pendampingan, serta bantuan diakonia transformatif. Ketiga adalah Resource. Resource adalah sumber daya yang memenuhi kebutuhan jangkauan-jangkauan pada kedua aspek sebelumnya. Kita dapat menerjemahkannya dengan sumber yang memberdayakan. Sumber ini dapat mencakup arahan konselor (orang yang berkompeten di bidang pastoral), pendapat dari organisasi sosial dan instansi terkait. ${ }^{40}$ Komunitas diresourcing oleh mereka juga untuk kelengkapan pelayanan pastoralnya.

\footnotetext{
${ }^{36}$ Ronald Hughes, "Shepherding The Flock: C.A.R.E. - A Model For Pastoral Ministry", Disertasi, (Liberty Baptist Theological Seminary, 2015)

${ }^{37}$ Ibid.

${ }^{38}$ Pakpahan, Binsar. "Sharing a Common Story for an Indonesian Context," Journal of Reformed Theology, Vol. 2, No. 1 (2008); 63-74

${ }^{39}$ Hughes, "Shepherding The Flock: C.A.R.E

${ }^{40}$ Ibid.
} 
Keempat, Equip. Equip adalah proses memenuhi kebutuhan pelayanan pastoral kepada anggota jemaat awam. ${ }^{41}$ Kita dapat menerjemahkannya sebagai kelengkapan. Keempat berkaitan dengan yang ketiga, yang terdiri dari pelatihan keterampilan dasar melayani, persiapan konseling, dan pelatihan ritual, seperti doa dan berkata-kata bijak. Di dalam model ini, keempatnya dilakukan secara simetris oleh pendeta, majelis jemaat, dan anggota jemaat awam, tanpa adanya intervensi berbasis status tahbisan mereka. Memang, komunikasi dan kualitas berkomunitas menjadi faktor pendukung yang penting.

Nuansa komunal dari konstruksi akronim pelayanan pastoral tersebut menjadi penanda pentingnya untuk berkolaborasi dalam pengembangan pelayanan pastoral di dalam konteks masing-masing, dan membawa harapan tentang kemungkinan melibatkan komunitas. Secara khusus, dalam kehidupan bergereja yang tidak lepas dari partisipasi anggota jemaat. Dengan demikian, pengembangan model yang ada ini memungkinkan komunitas dan partisipasi jenis apa yang dapat mereka tunjukkan.

\section{Kesimpulan}

Dari pencarian model pelayanan pastoral yang kontekstual, jelas bahwa kita telah menghasilkan model pelayanan pastoral berbasis komunal. Kualitas berkomunitas menjadi faktor penentu aktivitas pastoral yang ada. Rasanya tampak jelas bahwa berteologi pastoral kontekstual adalah proses yang tidak akan pernah usai. Kiranya paradigma komunal yang di dalamnya berupaya menunju pelayanan pastoral bersama komunitas dapat disadari pada saat sekarang, ketika banyak gereja-gereja di Indonesia yang memahami pelayanan pastoral hanya sebatas pelayanan pendeta. Permasalahannya ialah bagaimana jika pendeta tidak dengan tekun menjalankan tugasnya itu? Dan gereja kehilangan fungsi pastoralnya? Pelayanan bersama komunitas akan bertanggung-jawab atas itu.

\section{Referensi}

Abineno, J. L. Ch. Pedoman Praktis untuk Pelayanan Pastoral, cet. ke-2. Jakarta: BPK Gunung Mulia, 1999 . Jemaat. Jakarta: BPK Gunung Mulia, 1987.

. Percakapan Pastoral dalam Praktik, Jakarta: BPK Gunung Mulia, 1982.

Douglas, Scott. "Developing Leaders for Pastoral Ministry," Journal of Applied Christian Leadership; Vol. 8, No. 2 (2014), 84-90.

Gerkin, Charles. Konseling Pastoral dalam Transisi, terj. Adji Sutama. Kanisius: Yogyakarta, 1992.

Horton, Michael. Introducing Covenant Theology, Grand Rapids: Baker Book Publishing, 2009.

Hiltner, Seward. Preface to Pastoral Theology, Nashville: Abingdon Press, 1958

\footnotetext{
${ }^{41}$ Ibid.
} 
"Pengantar Untuk Teologi Pastoral", terj. Hendro Susanto dalam Teologi dan Praksis Pastoral: Antologi Teologi Pastoral, ed. Tjaard G. Hommes dan E. Gerrit Singgih. Yogyakarta: Penerbit Kanisius. 1992

Hughes, Ronald. "Shepherding The Flock: C.A.R.E. - A Model For Pastoral Ministry", Disertasi, Liberty Baptist Theological Seminary, 2015

Hunter, Rodney J, peny. Dictionary of Pastoral Care and Counseling, Nashville: Abingdon Press, s.v. Pastoral Care (L. O. Mills), 1990

Kwon, Soo-Young. "Codependence and Interdependence: Cross-Cultural Reappraisal of Boundaries," Journal Pastoral Psychology, Vol. 50, No. 1 (2001); 39-52.

MacLean, Catherine. "Showing Up: The Essential Practice of Pastoral Care," Touchstone Journal, 2017

McClure, Barbara. Moving Beyond Individualism in Pastoral Care and Counseling: Reflections on theory, theology and practice, Oregon: Cascade Book, 2010

Messakh, Besly. "Menuju Pelayanan Pastoral yang Relevan dan Kontekstual," Jurnal Theologia in Loco; Vol. 1, No. 1, (2018); 22-40.

Morgan, Edward. "Implication of the Masculine and the Feminine in Pastoral Ministry," The Journal of Pastoral Care; Vol. XXXIV, No. 4, (1980); 268-277.

Pakpahan, Binsar. "Sharing a Common Story for an Indonesian Context," Journal of Reformed Theology, Vol. 2, No. 1 (2008); 63-74

Patton, John. 1993. Pastoral Care in Context: An Introduction to Pastoral Care, Louisville: Westminster.

Rey, Kevin Tonny. "Konstruksi Teologi Dalam Konteks Reposisi Pemikiran Warga Gereja." EPIGRAPHE: Jurnal Teologi dan Pelayanan Kristiani 2, no. 1 (2018): 1-13. www.stttorsina.ac.id/jurnal/index.php/epigraphe.

Riech, Warren, peny. 1995. Encyclopedia of Bioethics, New York: Simon \& Schuster, s.v. Pastoral Care (Rodney J. Hunter).

Scheib, Karen. "Contributions of Communion Ecclesiology To The Communal-Contextual Model of Care," The Journal of Pastoral Theology: Vol. 12, No. 2 (2002); 28-50.

Siahaan, Harls Evan R. "Aktualisasi Pelayanan Karunia Di Era Digital." EPIGRAPHE: Jurnal Teologi dan Pelayanan Kristiani 1, no. 1 (2017): 23-38. www.stttorsina.ac.id/jurnal/index.php/epigraphe.

Susanto, Daniel. "Dalam Sekilas tentang Pelayanan Pastoral di Indonesia," Pelayanan Pastoral Holistik, peny. Daniel Susanto, Jakarta: Majelis GKI Menteng, 2010.

Whipp, Margareth. Pastoral Theology, London: SCM Press., 2013 